\title{
Quinolines from the cyclocondensation of isatoic anhydride with ethyl acetoacetate: preparation of ethyl 4-hydroxy-2-methylquinoline-3-carboxylate and derivatives
}

\author{
Nicholas G. Jentsch, Jared D. Hume, Emily B. Crull, Samer M. Beauti, Amy H. Pham, \\ Julie A. Pigza, Jacques J. Kessl and Matthew G. Donahue*
}

\section{Full Research Paper}

Address:

Department of Chemistry and Biochemistry, University of Southern Mississippi, 118 College Drive \#5043, Hattiesburg, MS 39406, USA

Email:

Matthew G. Donahue* - matthew.donahue@usm.edu

* Corresponding author

Keywords:

cyclodehydration; HIV integrase; isatoic anhydride; masked acyl

cyanide; quinoline

\author{
Beilstein J. Org. Chem. 2018, 14, 2529-2536. \\ doi:10.3762/bjoc. 14.229 \\ Received: 11 June 2018 \\ Accepted: 04 September 2018 \\ Published: 28 September 2018 \\ Associate Editor: I. R. Baxendale \\ (C) 2018 Jentsch et al.; licensee Beilstein-Institut. \\ License and terms: see end of document.
}

\begin{abstract}
A convenient two-step synthesis of ethyl 4-hydroxy-2-methylquinoline-3-carboxylate derivatives has been developed starting from commercially available 2-aminobenzoic acids. In step 1, the anthranilic acids are smoothly converted to isatoic anhydrides using solid triphosgene in THF. In step 2, the anhydride electrophiles are reacted with the sodium enolate of ethyl acetoacetate, generated from sodium hydroxide, in warm $N, N$-dimethylacetamide resulting in the formation of substituted quinolines. A degradation-buildup strategy of the ethyl ester at the 3-position allowed for the construction of the $\alpha$-hydroxyacetic acid residue required for the synthesis of key arylquinolines involved in an HIV integrase project.
\end{abstract}

\section{Introduction}

In stark contrast to the prevalence of the quinoline heterocycle in natural products [1], quinolines are only present in approximately $2 \%$ of FDA approved prescription pharmaceuticals [2]. Recently, 2,3,4-trisubstituted arylquinolines such as BI 224436 $\mathbf{1}[3,4]$ and $\mathbf{2}[5,6]$ have been shown to exhibit inhibitory activity against HIV-1 integrase that is essential for viral replication through integration of viral DNA into host cell chromatin (Figure 1) [7-9]. In contrast to the FDA approved integrase strand transfer inhibitors (INSTIs) dolutegravir, elvitegravir, and raltegravir, arylquinolines $\mathbf{1}$ and $\mathbf{2}$ bind to a non-catalytic site of integrase (NCINI) via allosteric binding inhibition.

Structure-activity relationship studies have indicated that the 2-methyl and 3-acetic acid residues are crucial to maintaining the potency of this scaffold [10]. The Boehringer Ingelheim chemical development route toward the synthesis of quinoline $\mathbf{1}$ 


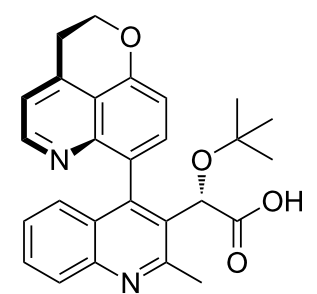

1<smiles>Cc1nc2ccc(Br)cc2c(-c2ccc(Cl)cc2)c1C(OC(C)(C)C)C(=O)O</smiles>

2
Figure 1: Investigational non-catalytic HIV-1 Integrase inhibitors.

is shown in Scheme 1 [11]. The northern tricyclic heterocycle at position 4 is installed by Suzuki coupling with iodide 3a that is synthesized in three steps from ethyl aryl oxalate 4a. The $\alpha$-ketoester side chain at position 3 was installed by selective halogen-metal exchange of iodide 5a with isopropylmagnesium chloride lithium chloride complex followed by quenching with ethyl chlorooxolate furnishing ethyl oxalate $4 \mathbf{a}$ in $29-79 \%$ yield [12]. This sequence works well with the unsubstituted benzene ring of the series a compounds where $\mathrm{R}=\mathrm{H}$. However, to access quinoline $\mathbf{2}$ with scaffolds such as $\mathbf{4 b}$ with halogen substitution in the benzene ring at the 5-, 6-, 7- or 8-positions would require a different strategy due to regioselectivity issues encountered in the Grignard acylation step $(\mathbf{5 b} \rightarrow \mathbf{4 b})$.

As part of an ongoing research program investigating new assays toward integrase inhibition, we desired to synthesize quinoline derivatives such as $\mathbf{2}$ with substitution in the benzene ring of the quinolone [13]. The known synthesis of quinoline core $\mathbf{8}$ has been published in a one-pot, two-step reaction from 4-bromoaniline (7) and diethyl acetylsuccinate in 36\% yield (Scheme 2) $[14,15]$. However, our attempts to repeat and scaleup this procedure beyond a few hundred milligrams were met with inconsistent results and variable yields. In our experience, this route is less advantageous due to: (1) the need for a prolonged room temperature condensation reaction time ( $>5$ days in a desiccator with phosphorus pentoxide) to form the initial vinylogous amide; (2) the use of expensive diphenyl ether, which has a nauseating odor, at 0.01 molar dilution at reflux $\left(259^{\circ} \mathrm{C}\right)$ to effect the ring closure via electrophilic aro- matic substitution; and (3) the aqueous work-up of this method which does not reliably produce a precipitate that can be filtered easily.



isatoic anhydride-ethyl acetoacetate cyclocondensation<smiles>[R]c1cccc2[nH]c(=O)oc(=O)c12</smiles>

9<smiles>CCOC(=O)CC(C)=O</smiles>

$\mathrm{NaH}, \mathrm{DMA}, 120^{\circ} \mathrm{C}$

this work:<smiles>[R]c1cccc2nc(C)c(C(=O)OCC)c(O)c12</smiles>

10

$$
\begin{aligned}
& \text { this work: } \\
& \mathrm{NaOH}, \mathrm{DMA}, 100^{\circ} \mathrm{C}
\end{aligned}
$$

Scheme 2: Quinoline ring condensation strategies.

Given the regioselectivity issues and practical challenges associated with the aniline cyclocondensation $(\mathbf{7} \rightarrow \mathbf{8})$, along with the scarcity of commercially available highly substituted quinolines, we sought to employ an entirely different tactic by utilizing 2H-3,1-benzoxazine-2,4(1H)-dione (isatoic anhydride) chemistry [16,17]. Isatoic anhydrides 9 are readily prepared from inexpensive, commercially available 2 -aminobenzoic acid derivatives (anthranilic acids) with a variety of carbonyl transfer reagents such as phosgene, triphosgene, carbonyldiimidazole, or diethyl carbonate. We therefore employed a modified Coppola quinoline synthesis method through the one-pot acylation of ethyl acetoacetate with isatoic anhydrides followed by dehydrative intramolecular cyclization to access the desired quinoline scaffold 10 [18]. We replaced sodium hydride as the base required to generate the enolate of ethyl acetoacetate with sodium hydroxide $[19,20]$. The use of sodium hydride is of particular concern upon reaction scale-up due to limited solubility in organic solvents and the production of flammable hydrogen gas $[21,22]$. Sodium hydroxide avoids the off-gassing of hydrogen<smiles></smiles> 
and produces water instead, thereby avoiding the use of any special safety precautions.

\section{Results and Discussion}

The anhydrides $\mathbf{9 a}-\mathbf{h}$ were readily accessible by treatment of anthranilic acids $\mathbf{A A}$ with one equivalent of triphosgene in refluxing tetrahydrofuran at 0.36 molar concentration (Scheme 3). This procedure is an alternative to the existing published protocol that relies on the use of toxic phosgene gas [23] as the acylating agent by replacing it with the non-volatile and weighable solid triphosgene [24,25]. After stirring for 12 hours, the reaction mixtures were quenched by pouring into approximately 30 volumes of water $(1$ volume $=10 \mathrm{~mL}$ of water per 1 gram of substrate) with subsequent stirring at room temperature for one hour. The isatoic anhydride products $9 \mathbf{a}-\mathbf{h}$ typically precipitate out of solution and are readily collected by vacuum filtration. This reverse aqueous quench provides sufficiently pure material without the need for extraction with organic solvent or additional purification. The reactions typically produced high purity products with some colored impurities that were removed by slurring the crude filter cake in methanol followed by vacuum filtration. HPLC analysis of the filtrate showed minuscule loss of product due to this trituration. The reaction is tolerant to halide substitution at the 6-, 7-, and

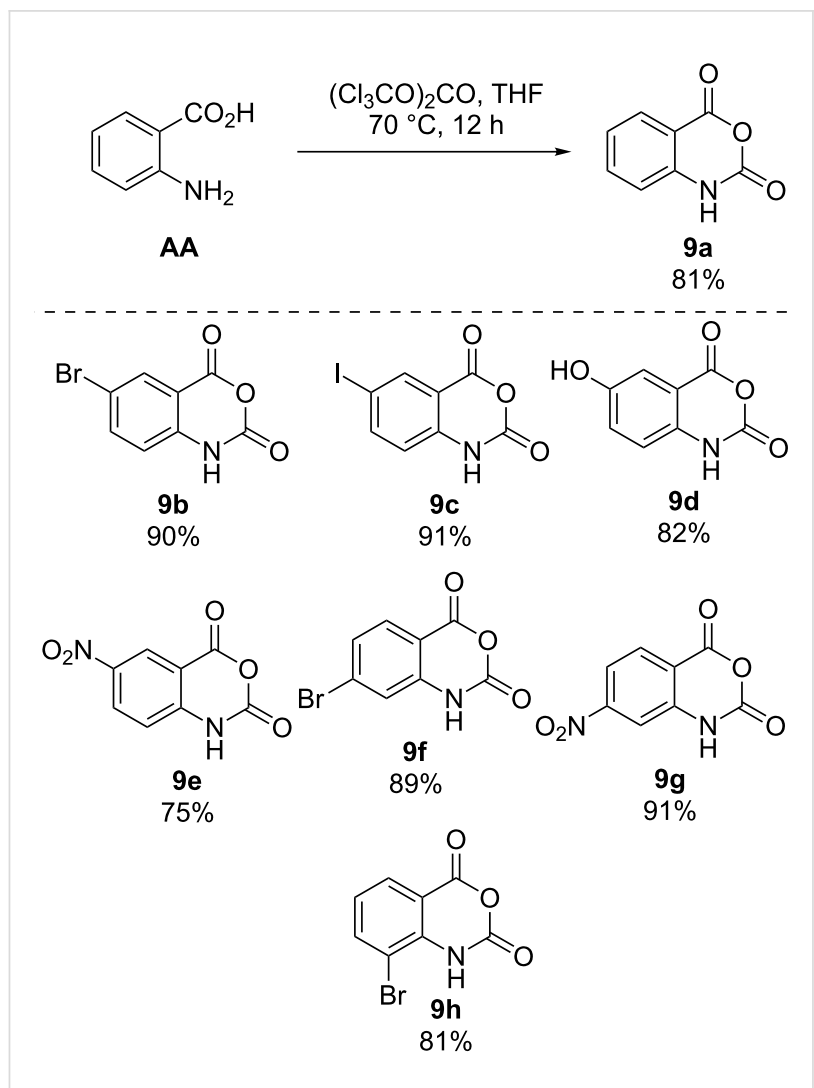

Scheme 3: Isatoic anhydrides from anthranilic acids with triphosgene. 8-positions (9b, 9c, 9f, 9h). The unprotected hydroxy group in 9d gave reasonably high yield as did electron-withdrawing nitro groups in the 6- and 7-positions $(9 \mathrm{e}, 9 \mathrm{~g})$.

The substituted isatoic anhydrides from Scheme 3 were then subjected to the modified Coppola conditions for the synthesis of 2-methylquinoline derivatives 10a-h (Scheme 4). Most significantly, the investigation found that one equivalent of solid sodium hydroxide in 0.6 molar $N, N$-dimethylacetamide at $100{ }^{\circ} \mathrm{C}$ was able to achieve the same result as the Coppola protocol $\left(\mathrm{NaH}, \mathrm{DMA}, 120^{\circ} \mathrm{C}\right)$. While the use of sodium hydroxide results in the production of water in the reaction medium, we observed no evidence of hydrolysis of the ethyl esters even at elevated temperatures. The reaction is operationally robust and can be carried out without rigorous exclusion of moisture or degassing protocols. As with the isatoic anhydride step, the crude reaction mixtures were poured directly into approximately 30 volumes of water and produced solid material that was readily collected via vacuum filtration. It should be noted that addition of water directly to the reaction vessel did<smiles>CCOC(=O)c1c(C)nc2ccc([N+](=O)[O-])cc2c1O</smiles>

Scheme 4: Substituted 2-methyl-4-hydroxyquinolines from isatoic anhydrides and ethyl acetoacetate. 
not have the same outcome, typically resulting in oiling out of the product, and requiring organic solvent extraction. The yields ranged from modest (47\%) to excellent $(97 \%)$ on scales from 1 gram up to 25 gram batches with spectral data matching known quinolones [26].

A plausible mechanism for the formation of the quinoline is shown in Scheme 5 [27]. After initial formation of the enolate of ethyl acetoacetate with sodium hydroxide, water is generated in the reaction mixture, which then serves as a proton transfer

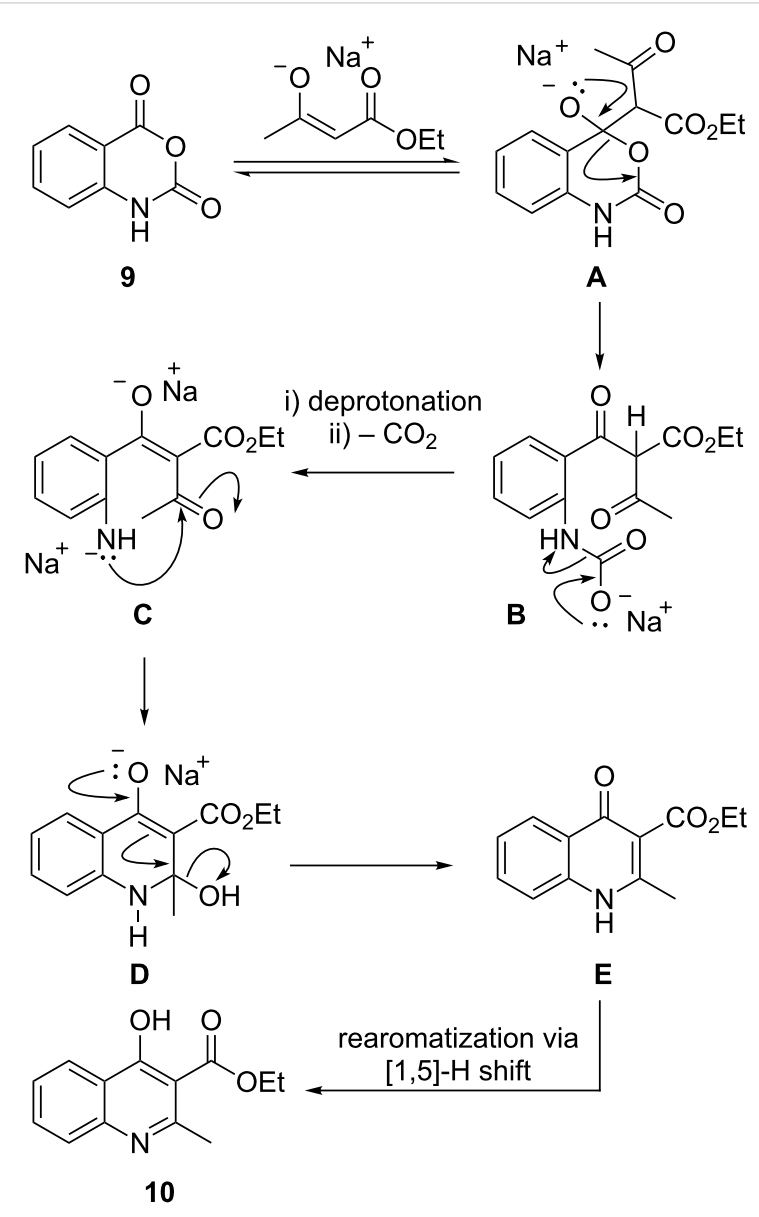

Scheme 5: Mechanistic hypothesis for the cyclocondensation reaction. agent. The resulting sodium enolate regioselectively attacks the more electrophilic ester carbonyl of the isatoic anhydride forming tetrahedral intermediate A. Subsequent collapse of the $\mathrm{sp}^{3}$-hybridized carbon to the ketone $\mathbf{B}$ with concomitant expulsion of carbon dioxide and enolization affords the ketone $\mathbf{C}$. The anion of the aniline nitrogen then attacks the ketone carbonyl via intramolecular 6-exo-trig cyclization and subsequent proton transfer to the aminal oxygen D. Elimination of the 2-hydroxy group from $\mathbf{D}$ then affords the 4-quinolone $\mathbf{E}$ that tautomerizes via [1,5]-hydride shift to form quinoline $\mathbf{1 0 .}$

Given the success of employing ethyl acetoacetate in the quinoline cyclocondensation reaction (Scheme $4, \mathbf{9} \rightarrow \mathbf{1 0}$ ), we hypothesized that ethyl acetopyruvate could install the desired ethyl 2-oxoacetate residue at the 3-position as in $\mathbf{1 1}$ that is required for the synthesis of quinolines $\mathbf{1}$ and $\mathbf{2}$ (Scheme 6). Whereas with ethyl acetoacetate as shown in Scheme 5 can only condense to form quinolines of type $\mathbf{1 0}$ via $\mathbf{C} \rightarrow \mathbf{D}$, the ethyl acetopyruvate has two carbonyls a and $\mathrm{b}$ as depicted in $\mathbf{1 3}$ that result in regioisomeric products upon ring closure. The desired quinoline $\mathbf{1 1}$ requires ring closure onto carbonyl $\mathrm{b}$.

To that end, ethyl sodioacetopyruvate was prepared via Claisen condensation of acetone with diethyl oxalate and sodium ethoxide in ethanol [28]. Isatoic anhydride 9 f was then added to the solid enolate and both were dissolved in DMA and warmed to $60{ }^{\circ} \mathrm{C}$ for 12 hours. Following the general work-up protocol as described for Scheme 4, a light tan solid was isolated in modest yield after trituration with methanol that was determined to be exclusively compound $\mathbf{1 2}$ by NMR. The formation of either regioisomer $\mathbf{1 1}$ (via b) or $\mathbf{1 2}$ (via a) results from 6-exotrig cyclization of the common nucleophilic acyl substitution intermediate 13. The ${ }^{13} \mathrm{C}$ NMR data of the product has a singlet at $\delta 199 \mathrm{ppm}$ that shows a correlation by HMBC to the singlet integrating to three protons in the ${ }^{1} \mathrm{H}$ NMR at $\delta 2.52 \mathrm{ppm}$. That same proton singlet in the HMBC only shows one other correlation to a carbon singlet at $\delta 121.6 \mathrm{ppm}$. These methyl group correlations can only be observed in compound $\mathbf{1 2}$ as the $\mathrm{HMBC}$ experiment detects two and three-bond correlations. In<smiles>CCOC(=O)C(=O)C(=O)C(C(=O)OCC)C(=O)c1ccc(Br)cc1N</smiles> 
11, correlation of the methyl singlet to the ketone is ${ }^{4} J_{\mathrm{CH}}$ and would not be detected. The $\alpha$-keto carbonyl group a in compound 11 would be expected to have a chemical shift more upfield than $\delta 199.3 \mathrm{ppm}$. Therefore, the product was determined to unequivocally be the undesired quinoline $\mathbf{1 2}$.

We then turned to a functional group transformation of the ethyl ester at the 3-position to address the acetic acid sidechain problem (Scheme 7). First, the 4-hydroxy group in quinoline $\mathbf{1 0 f}$ was substituted for chlorine with neat phosphorus oxychloride to afford chloride $\mathbf{1 4}$ in $91 \%$ yield. The ethyl ester was then smoothly reduced with DIBAL to the benzyl alcohol. While the

$$
\text { (2. }
$$

Scheme 7: Elaboration of the benzoic acid ethyl ester to the acetic acid residue. in-process analysis (TLC and HPLC) indicated quantitative reduction, the isolated yields from the reductions were only poor to modest despite utilizing standard workup conditions with sodium potassium tartrate. Subsequent oxidation of the primary alcohol to the aldehyde $\mathbf{1 5}$ was accomplished with the pyridine sulfur trioxide complex in 52\% yield over two-steps [29].

The carbon atom at the acid oxidation state was installed by addition of trimethylsilyl cyanide to the aldehyde $\mathbf{1 5}$ in the presence of lithium chloride in THF [30]. Initially, the trimethylsilyl cyanohydrin 16 was subjected to solvolysis in ethanol with aqueous sulfuric acid. Unfortunately, those conditions resulted in displacement of the 4-chloro substituent with ethanol giving the 4-ethyl ether $\mathbf{1 7}$ in 35\% yield. To circumvent this undesired substitution at the 4-position, the cyanohydrin $\mathbf{1 6}$ was hydrolyzed by a two-step process. First, hydrogen chloride in ethanol (3.3 molar) was used to produce the imidate $\mathbf{1 8}$ in quantitative yield. The structure of $\mathbf{1 8}$ was verified by NMR to prove that the 4-position had not suffered displacement by ethanol. Subsequent hydrolysis of $\mathbf{1 8}$ with dilute aqueous hydrochloric acid afforded the desired ethyl ester 19 in 59\% yield. Given the three steps required to convert the aldehyde $\mathbf{1 5}$ into the desired $\alpha$-hydroxy acetic acid ethyl ester $\mathbf{1 9}$, we decided to pursue a more direct one-carbon homologation procedure.

We envisioned a milder alternative to the acidic conditions required for cyanide hydrolysis that would provide the side chain at the correct oxidation in one pot. To that end, we turned to masked acyl cyanide (MAC) chemistry [31] in which the reagent 20 acts as an acyl anion via umpolung reactivity [32]. With the aldehyde $\mathbf{1 5}$ in hand, homologation involving the addition of the MAC reagent $\mathbf{2 0}$ afforded the TBS protected $\alpha$-hydroxyacetic acid ethyl ester $\mathbf{2 1}$ in in $76 \%$ yield (Scheme 8 ).

Based on the purported mechanistic reasoning of Nemoto, addition of the methine anion of $\mathbf{2 0}$ to $\mathbf{1 5}$ proceeds to the intermediate alkoxide $\mathbf{G}$ that undergoes a [1,4]-shift of the silicon group with concomitant ejection of cyanide anion to form acyl cyanide $\mathbf{H}$ [33]. As the reaction is run in the presence of

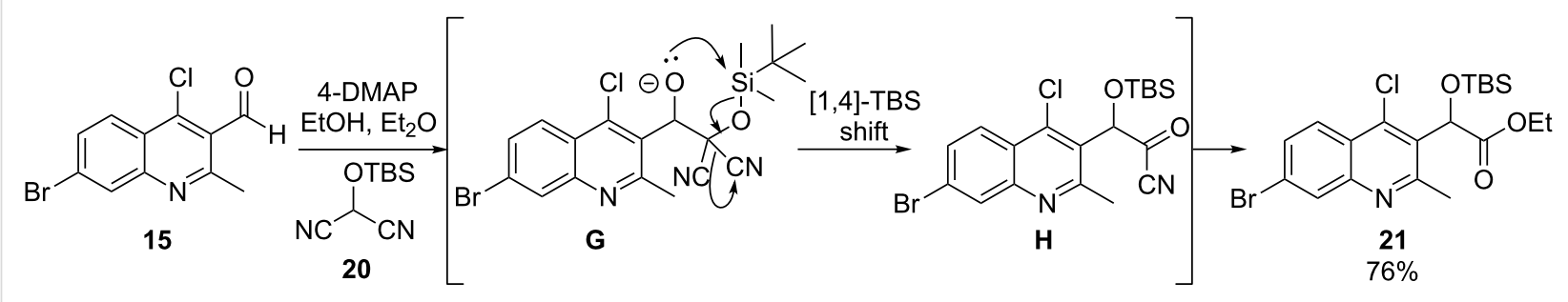


ethanol, nucleophilic acyl substitution of cyanide $H$ for the ethoxy group furnishes the ethyl ester $\mathbf{2 1}$ in one pot. We were therefore able to construct the desired benzene substituted quinoline $\mathbf{2 1}$ in six steps from 2-amino-4-bromobenzoic acid in $31 \%$ overall yield.

\section{Conclusion}

In conclusion, an efficient route for the synthesis of substituted quinolines $\mathbf{1 0 a}-\mathbf{h}$ has been demonstrated from commercially available anthranilic acids AA (Scheme 4). This strategy achieved the replacement of sodium hydride with sodium hydroxide thereby obviating any special equipment requiring the capture or scrubbing of hydrogen gas evolved. The extension of the 3-position ethyl ester into the $\alpha$-tert-butoxy acetic acid residue was also demonstrated via a cyanohydrin-hydrolysis route $(\mathbf{1 0 f} \rightarrow \mathbf{1 9})$ and an umpolung acyl addition strategy $(\mathbf{1 0 f} \rightarrow \mathbf{2 1})$. The development of a library of quinoline scaffolds is currently underway within our lab utilizing this synthetic process [34,35].

\section{Experimental General procedure for isatoic anhydride synthesis}

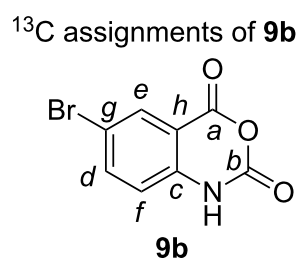

6-Bromo-2H-benzo $[d][1,3]$ oxazine-2,4(1H)-dione $(9 \mathrm{~b})$. A $500 \mathrm{~mL}$ single neck round-bottomed flask equipped with a football-shaped PTFE stirring bar $(16 \mathrm{~mm} \times 37 \mathrm{~mm})$ was charged with 2-amino-5-bromobenzoic acid $(10.0 \mathrm{~g}, 46.3 \mathrm{mmol}$, 1.0 equiv) followed by the addition of tetrahydrofuran $(230 \mathrm{~mL}$, 0.2 molar) and solid triphosgene ( $13.7 \mathrm{~g}, 46.3 \mathrm{mmol}, 1.0$ equiv) resulting in a suspension. The reaction vessel was placed into a fitted metal heating mantle and the neck was equipped with a 24/40 Liebig condenser. The suspension was stirred (500 rpm) and the heating mantle set to $70{ }^{\circ} \mathrm{C}$. The suspension became homogenous before a white solid precipitated out after about 30 minutes at $70^{\circ} \mathrm{C}$. The heterogeneous reaction mixture was aged for 12 hours then cooled to room temperature $\left(25^{\circ} \mathrm{C}\right)$. The slurry was poured into a $600 \mathrm{~mL}$ beaker equipped with overhead mechanical stirrer (PTFE $75 \mathrm{~mm}$ paddle) containing $250 \mathrm{~mL}$ of deionized water. With vigorous stirring, the mixture became homogenous followed by precipitation of a pale white solid. The solid was collected by vacuum filtration on a Büchner funnel (7.6 cm diameter) with Whatman \#1 filter paper $(70 \mathrm{~mm})$ and air pulled through for 5 minutes. The material was transferred to a $250 \mathrm{~mL}$ Erlenmeyer flask equipped with cylindrical stir bar and $50 \mathrm{~mL}$ of methanol was added. The slurry was stirred for 10 minutes and then collected by vacuum filtration. The filter cake was dried under vacuum $(0.1 \mathrm{mmHg}$ at $25^{\circ} \mathrm{C}$ ) for 12 hours to afford $9 \mathbf{b}$ as a white powder (90\% yield). Physical characteristics of $9 \mathbf{b}$ : white powder with $95.4 \%$ purity as determined by quantitative ${ }^{1} \mathrm{H}$ NMR using maleic acid as the internal standard; $\mathrm{mp}>270{ }^{\circ} \mathrm{C}$; IR (solid) $\mathrm{cm}^{-1}$ : 3170,1751 ; ${ }^{1} \mathrm{H}$ NMR (DMSO- $\left.d_{6}, 400 \mathrm{MHz}\right) \delta 11.86(\mathrm{~s}, 1 \mathrm{H}, \mathrm{N}-\mathrm{H}), 7.98(\mathrm{~d}$, $J=2.3 \mathrm{~Hz}, 1 \mathrm{H}, \mathrm{C} e-\mathrm{H}), 7.88(\mathrm{dd}, J=8.7,2.3 \mathrm{~Hz}, 1 \mathrm{H}, \mathrm{C} d-\mathrm{H})$, $7.19(\mathrm{~d}, J=8.7 \mathrm{~Hz}, 1 \mathrm{H}, \mathrm{C} f-\mathrm{H}) ;{ }^{13} \mathrm{C}$ NMR (DMSO- $d_{6}$, $100 \mathrm{MHz}) \delta 158.8(\mathrm{~s}, \mathrm{C} a), 146.7(\mathrm{~s}, \mathrm{Cb}), 140.6(\mathrm{~s}, \mathrm{C} c), 139.3$ $(\mathrm{d}, \mathrm{Cd}), 130.5(\mathrm{~d}, \mathrm{Ce}), 117.6(\mathrm{~d}, \mathrm{C} f), 114.5$ (s, Cg), 112.4 (s, Ch); HRMS (ESI): calcd for $\left[\mathrm{C}_{8} \mathrm{H}_{4} \mathrm{BrNO}_{3}+\mathrm{Na}\right]^{+} 263.926677$; found: 263.926475; anal. calcd for $\mathrm{C}_{8} \mathrm{H}_{4} \mathrm{BrNO}_{3}$ : C, 50.34; $\mathrm{H}$, 3.90; found: C, 49.98; H, 3.80 .

\section{General procedure for quinoline synthesis}

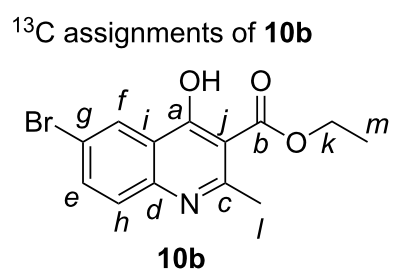

Ethyl 6-bromo-4-hydroxy-2-methyl-3-carboxylate (10b). To a $250 \mathrm{~mL}$ single-necked round bottom flask equipped with football-shaped PTFE stir bar $(16 \mathrm{~mm} \times 37 \mathrm{~mm})$ was added isatoic anhydride 9b (10.85 g, $44.8 \mathrm{mmol}, 1.0$ equiv), ethyl acetoacetate (11.3 mL, $89.7 \mathrm{mmol}, 2.0$ equiv), and $N, N$-dimethylacetamide (75 mL, 0.6 molar) resulting in a clear yellow solution. To the reaction solution was then added solid sodium hydroxide ( $1.79 \mathrm{~g}, 44.8 \mathrm{mmol}, 1.0$ equiv) that dissolved over time. The reaction vessel was placed in a fitted metal heating mantle and heated at $100{ }^{\circ} \mathrm{C}$ for 12 hours. The reaction solution was cooled to room temperature $\left(25^{\circ} \mathrm{C}\right)$ and poured into a $500 \mathrm{~mL}$ beaker equipped with cylindrical PTFE stir bar $(16 \mathrm{~mm} \times 37 \mathrm{~mm})$ containing $250 \mathrm{~mL}$ of deionized water causing a beige solid to precipitate out of solution. The solid was collected on a Büchner funnel (7.6 cm diameter) with Whatman \#1 filter paper $(70 \mathrm{~mm})$ and air dried by pulling a vacuum through for 10 minutes. The material was further dried in a vacuum oven $(0.1 \mathrm{mmHg}$ at $25^{\circ} \mathrm{C}$ ) for 24 hours to afford $11.1 \mathrm{~g}$ of $\mathbf{1 0 b}$ as a white powder ( $80 \%$ yield). Physical and spectroscopic characteristics of $\mathbf{1 0 b}$ : white powder with $97.9 \%$ purity as determined by quantitative ${ }^{1} \mathrm{H}$ NMR using maleic acid as the internal standard; mp 270-272 ${ }^{\circ} \mathrm{C}$; IR (solid) $\mathrm{cm}^{-1} 1705 ;{ }^{1} \mathrm{H}$ NMR (DMSO- $d_{6}$, $400 \mathrm{MHz}) \delta 12.03(\mathrm{~s}, 1 \mathrm{H}, \mathrm{O}-\mathrm{H}), 8.13(\mathrm{~d}, J=2.3 \mathrm{~Hz}, 1 \mathrm{H}, \mathrm{C} f-\mathrm{H})$, $7.82(\mathrm{dd}, J=8.8,2.4 \mathrm{~Hz}, 1 \mathrm{H}, \mathrm{Ce}-\mathrm{H}), 7.51$ (d, $J=8.8 \mathrm{~Hz}, 1 \mathrm{H}$, $\mathrm{C} h-\mathrm{H}), 4.24$ (q, J= 7.1 Hz, 2H, Ck-H), 2.39 (s, 3H, Cl-H), 1.27 
(t, $J=7.1 \mathrm{~Hz}, 1 \mathrm{H}, \mathrm{Cm}-\mathrm{H}) ;{ }^{13} \mathrm{C}$ NMR (DMSO- $\left.d_{6}, 100 \mathrm{MHz}\right)$ $\delta 172.0(\mathrm{~s}, \mathrm{C} a), 166.4$ (s, Cb), 149.4 (s, Cc), 138.0 (s, Cd), 134.9 (d, Ce), 127.1 (d, Cf), 126.0 (s, Cg), 120.6 (d, Ch), 116.3 (s, Ci), 115.0 (s, Cj), 60.4 (t, Ck), 18.2 (q, Cl), 14.1 (q, Cm); HRMS (ESI): calcd for $\left[\mathrm{C}_{13} \mathrm{H}_{12} \mathrm{BrNO}_{3}+\mathrm{Na}\right]^{+} 331.989277$; found: 331.988788; anal. calcd for $\mathrm{C}_{13} \mathrm{H}_{12} \mathrm{BrNO}_{3}$ : C, 39.70; $\mathrm{H}$, 1.67; found C, 39.51; H, 1.74 .

\section{Supporting Information}

\section{Supporting Information File 1}

Experimental procedures and analytical data. [https://www.beilstein-journals.org/bjoc/content/ supplementary/1860-5397-14-229-S1.pdf]

\section{Supporting Information File 2}

IR, NMR and mass spectra, as well as elemental analyses. [https://www.beilstein-journals.org/bjoc/content/ supplementary/1860-5397-14-229-S2.pdf]

\section{Acknowledgements}

JK thanks the National Institute of Allergy and Infectious Disease for AI127282. Funding for the Bruker UltraShield Plus $400 \mathrm{MHz}$ NMR and ThermoFinnigan LXQ ESI LC-MS used in this research was provided by National Science Foundation Major Research Instrumentation under Grant Numbers 0840390 and 0639208, respectively. NGJ, JDH, and EBC thank the USM INTERFACE National Science Foundation National Research Trainee under Grant Number 1449999. We thank the University of Southern Mississippi Office of the Vice President for Research for financial support, laboratory space and facilities. MGD is a 2015 and 2018 recipient of the Lucas Award for Faculty Excellence sponsored by the USM Office of the Provost.

\section{ORCID ${ }^{\circledR}$ iDs}

Nicholas G. Jentsch - https://orcid.org/0000-0001-8264-9222 Jared D. Hume - https://orcid.org/0000-0002-0214-3190 Emily B. Crull - https://orcid.org/0000-0003-3839-7579 Samer M. Beauti - https://orcid.org/0000-0003-0844-7686 Amy H. Pham - https://orcid.org/0000-0002-0969-6679 Julie A. Pigza - https://orcid.org/0000-0002-1289-5679 Jacques J. Kessl - https://orcid.org/0000-0001-8103-6678 Matthew G. Donahue - https://orcid.org/0000-0002-2608-1529

\section{References}

1. Chung, P.-Y.; Bian, Z.-X.; Pun, H.-Y.; Chan, D.; Chan, A. S.-C.; Chui, C.-H.; Tang, J. C.-O.; Lam, K.-H. Future Med. Chem. 2015, 7, 947-967. doi:10.4155/fmc.15.34

2. Vitaku, E.; Smith, D. T.; Njardarson, J. T. J. Med. Chem. 2014, 57, 10257-10274. doi:10.1021/jm501100b
3. Fader, L. D.; Malenfant, E.; Parisien, M.; Carson, R.; Bilodeau, F.; Landry, S.; Pesant, M.; Brochu, C.; Morin, S.; Chabot, C.; Halmos, T.; Bousquet, Y.; Bailey, M. D.; Kawai, S. H.; Coulombe, R.; LaPlante, S.; Jakalian, A.; Bhardwaj, P. K.; Wernic, D.; Schroeder, P.; Amad, M.; Edwards, P.; Garneau, M.; Duan, J.; Cordingley, M.; Bethell, R.; Mason, S. W.; Bös, M.; Bonneau, P.; Poupart, M.-A.; Faucher, A.-M.; Simoneau, B.; Fenwick, C.; Yoakim, C.; Tsantrizos, Y. ACS Med. Chem. Lett. 2014, 5, 422-427. doi:10.1021/ml500002n

4. Fenwick, C.; Amad, M.; Bailey, M. D.; Bethell, R.; Bös, M.; Bonneau, P.; Cordingley, M.; Coulombe, R.; Duan, J.; Edwards, P.; Fader, L. D.; Faucher, A.-M.; Garneau, M.; Jakalian, A.; Kawai, S.; Lamorte, L.; LaPlante, S.; Luo, L.; Mason, S.; Poupart, M.-A.; Rioux, N.; Schroeder, P.; Simoneau, B.; Tremblay, S.; Tsantrizos, Y.; Witvrouw, M.; Yoakim, C. Antimicrob. Agents Chemother. 2014, 58, 3233-3244. doi:10.1128/AAC.02719-13

5. Kessl, J. J.; Jena, N.; Koh, Y.; Taskent-Sezgin, H.; Slaughter, A.; Feng, L.; de Silva, S.; Wu, L.; Le Grice, S. F. J.; Engelman, A.; Fuchs, J. R.; Kvaratskhelia, M. J. Biol. Chem. 2012, 287, 16801-16811. doi:10.1074/jbc.M112.354373

6. Feng, L.; Sharma, A.; Slaughter, A.; Jena, N.; Koh, Y.; Shkriabai, N.; Larue, R. C.; Patel, P. A.; Mitsuya, H.; Kessl, J. J.; Engelman, A.; Fuchs, J. R.; Kvaratskhelia, M. J. Biol. Chem. 2013, 288, 15813-15820. doi:10.1074/jbc.M112.443390

7. Di Santo, R. J. Med. Chem. 2014, 57, 539-566. doi:10.1021/jm400674a

8. Quashie, P. K.; Sloan, R. D.; Wainberg, M. A. BMC Med. 2012, 10, 34. doi:10.1186/1741-7015-10-34

9. Ingale, K. B.; Bhatia, M. S. Antiviral Chem. Chemother. 2011, 22, 95-105. doi:10.3851/IMP1740

10. Christ, F.; Voet, A.; Marchand, A.; Nicolet, S.; Desimmie, B. A.; Marchand, D.; Bardiot, D.; Van der Veken, N. J.; Van Remoortel, B.; Strelkov, S. V.; De Maeyer, M.; Chaltin, P.; Debyser, Z. Nat. Chem. Biol. 2010, 6, 442-448. doi:10.1038/nchembio.370

11. Fandrick, K. R.; Li, W.; Zhang, Y.; Tang, W.; Gao, J.; Rodriguez, S.; Patel, N. D.; Reeves, D. C.; Wu, J.-P.; Sanyal, S.; Gonnella, N.; Qu, B.; Haddad, N.; Lorenz, J. C.; Sidhu, K.; Wang, J.; Ma, S.; Grinberg, N.; Lee, H.; Tsantrizos, Y.; Poupart, M.-A.; Busacca, C. A.; Yee, N. K.; Lu, B. Z.; Senanyake, C. H. Angew. Chem., Int. Ed. 2015, 54, 7144-7148. doi:10.1002/anie.201501575

12. Babudri, F.; Fiandanese, V.; Marchese, G.; Punzi, A. Tetrahedron 1996, 52, 13513-13520. doi:10.1016/0040-4020(96)00805-8

13. Kessl, J. J.; Sharma, A.; Kvaratskhelia, M. Methods Mol. Biol. (N. Y., NY, U. S.) 2016, 1354, 149-164. doi:10.1007/978-1-4939-3046-3_10

14. Chattha, F. A.; Munawar, M. A.; Ashraf, M.; Nagra, S. A.; Mehr-Un-Nisa; Fatima, I. J. Chil. Chem. Soc. 2012, 57, 1237-1239. doi:10.4067/S0717-97072012000300008

15. Avetisyan, A. A.; Aleksanyana, I. L.; Pivazyan, A. A. Russ. J. Org. Chem. 2004, 40, 889-891. doi:10.1023/B:RUJO.0000044555.03402.9b

16. Kappe, T.; Stadlbauer, W. Isatoic Anhydrides and Their Uses in Heterocyclic Synthesis in Advances in Heterocyclic Chemistry; Academic Press, 1981; Vol. 28, pp 127-182.

17. Coppola, G. M. Synthesis 1980, 505-536. doi:10.1055/s-1980-29110

18. Coppola, G. M.; Hardtmann, G. E. J. Heterocycl. Chem. 1979, 16, 1605-1610. doi:10.1002/jhet.5570160817

19. Mai, A.; Rotili, D.; Tarantino, D.; Ornaghi, P.; Tosi, F.; Vicidomini, C.; Sbardella, G.; Nebbioso, A.; Miceli, M.; Altucci, L.; Filetici, P. J. Med. Chem. 2006, 49, 6897-6907. doi:10.1021/jm060601m 
20. Goncalves, V.; Brannigan, J. A.; Whalley, D.; Ansell, K. H.; Saxty, B.; Holder, A. A.; Wilkinson, A. J.; Tate, E. W.; Leatherbarrow, R. J. J. Med. Chem. 2012, 55, 3578-3582. doi:10.1021/jm300040p

21. McCabe Dunn, J. M.; Duran-Capece, A.; Meehan, B.; Ulis, J.; Iwama, T.; Gloor, G.; Wong, G.; Bekos, E. Org. Process Res. Dev. 2011, 15, 1442-1446. doi:10.1021/op200114t

22. Banus, M. D.; Hinckley, A. A. Manufacture, Handling, and Uses of Sodium Hydride. Handling and Uses of the Alkali Metals; chapter 11; American Chemical Society, 1957; pp 106-117.

23. Wagner, E. C.; Fegley, M. F. Org. Synth. 1947, 27, 45. doi:10.15227/orgsyn.027.0045

24. Jamali, H.; Khan, H. A.; Stringer, J. R.; Chowdhury, S.; Ellman, J. A. J. Am. Chem. Soc. 2015, 137, 3616-3621. doi:10.1021/jacs.5b00095

25. Kim, H.; Park, G.; Park, J.; Chang, S. ACS Catal. 2016, 6, 5922-5929. doi:10.1021/acscatal.6b01869

26. Katritzky, A. R.; Takeuchi, Y.; Ternai, B.; Tiddy, G. J. T. Org. Magn. Reson. 1970, 2, 357-367. doi:10.1002/mrc.1270020407

27. Staiger, R. P.; Miller, E. B. J. Org. Chem. 1959, 24, 1214-1219. doi:10.1021/jo01091a013

28. Marvel, C. S.; Dreger, E. E. Org. Synth. 1926, 6, 40. doi:10.15227/orgsyn.006.0040

29. Parikh, J. R.; Doering, W. v. E. J. Am. Chem. Soc. 1967, 89, 5505-5507. doi:10.1021/ja00997a067

30. Kurono, N.; Yamaguchi, M.; Suzuki, K.; Ohkuma, T. J. Org. Chem. 2005, 70, 6530-6532. doi:10.1021/jo050791t

31. Nemoto, H.; Kubota, Y.; Yamamoto, Y. J. Org. Chem. 1990, 55, 4515-4516. doi:10.1021/jo00302a008

32. Seebach, D. Angew. Chem., Int. Ed. Engl. 1979, 18, 239-258. doi:10.1002/anie.197902393

33. Nemoto, H.; Ma, R.; Kawamura, T.; Yatsuzuka, K.; Kamiya, M.; Shibuya, M. Synthesis 2008, 3819-3827. doi:10.1055/s-0028-1083219

34. Patel, D.; Antwi, J.; Koneru, P. C.; Serrao, E.; Forli, S.; Kessl, J. J.; Feng, L.; Deng, N.; Levy, R. M.; Fuchs, J. R.; Olson, A. J.; Engelman, A. N.; Bauman, J. D.; Kvaratskhelia, M.; Arnold, E. J. Biol. Chem. 2016, 291, 23569-23577. doi:10.1074/jbc.M116.753384

35. Engelman, A.; Kessl, J. J.; Kvaratskelia, M. Curr. Opin. Chem. Biol. 2013, 17, 339-345. doi:10.1016/j.cbpa.2013.04.010

\section{License and Terms}

This is an Open Access article under the terms of the Creative Commons Attribution License (http://creativecommons.org/licenses/by/4.0). Please note that the reuse, redistribution and reproduction in particular requires that the authors and source are credited.

The license is subject to the Beilstein Journal of Organic Chemistry terms and conditions: (https://www.beilstein-journals.org/bjoc)

The definitive version of this article is the electronic one which can be found at: $\underline{\text { doi:10.3762/bjoc. } 14.229}$ 